\title{
PEMANFAATAN ALELOPATI BEBERAPA JENIS GULMA SEBAGAI HERBISIDA NABATI DAN DAMPAKNYA TERHADAP PERTUMBUHAN DAN HASIL BAWANG MERAH (Allium Ascalonicum L.)
}

\author{
IKHSAN HASIBUAN, PRIHANANI DAN DANNER SAGALA \\ Fakultas Pertanian Univ. Prof. Dr. Hazairin, S.H. Bengkulu
}

\begin{abstract}
The investigation was done to use the allelopathical potency of tested weeds as botanical herbicide, to find the best concentration of weed extract, to find the effect of allelopathy to either weed of onion or the onion. The experiment was carried out in experimental land of Agriculture Faculty, The University of Hazairin, North Bengkulu and Laboratory of Agronomy for four months.

The experiment was arranged factorially in a randomized block design with three replications. The kinds of extract weeds were Imperata cylindrica, Cyperus rotundus, Mikania micrantha and Ageratum conyzoides. Concentration was applied at $0 \%, 10 \%, 20 \%, 30 \%$, and $40 \%$.

The result concluded that extract, concentration or interaction of the two not only affected insignificant to growth and yield of onion but also dry weight of weed. However, extract of Cyperus rotundus tent to suppress the weed around the onion. Concentration of extract showed inconsistent response to all parameters. It probably because the concentration was still low so that the effect of maintenance was dominant.

Key Words: Allelopathy, Allium ascalonicum L., Bioherbicide, Growth and Yield

\section{PENDAHULUAN}

salah Keberadaan gulma merupakan pertumbuhan dan produktifitas tanaman khususnya tanaman bawang merah (Allium ascalonicum L). Menurut Sukman dan Yakup (2002) hal ini timbul akibat adanya persaingan antara tanaman dengan gulma baik dari segi kebutuhan hara, air, tempat, cahaya maupun udara.

Pengendalian gulma secara efektif dapat dilakukan antara lain dengan mengunakan bahan kimia khusus atau herbisida. Herbisida yang biasa digunakan petani dan mudah dijumpai di kios-kios pertanian adalah herbisida kimia. Namun penggunaan herbisida ini sering kali menimbulkan masalah akibat residu yang tertinggal di tanah yang dapat menggangu pertumbuhan tanaman (Saidi, 2005).

Selain itu herbisida kimia juga mahal dan sangat memberatkan petani.

Satu liter herbisida kimia harganya berkisar Rp. 40.000 - Rp. 60.000. Kebutuhan rata-rata herbisida per hektar adalah 5 liter, sehinnga petani harus mengeluarkan uang Rp. 200.000 - Rp. 300.000 untuk mengendalikan gulma tiap hektarnya. Hal ini mendorong untuk mencari alternatif herbisida yang lebih ramah lingkungan dengan harga yang lebih terjangkau.

Keberadaan gulma di sekitar kita dapat dimanfaatkan sebagai alternatif pengendalian gulma dengan mengolahnya menjadi herbisida botani. Hal ini memungkinkan karena beberapa jenis gulma mengandung zat alelopat atau elelopati yang dapat menghambat bahkan mematikan tumbuhan lain (Radosevich dan Holt, 1984). Gejala umum yang ditimbulkan akibat alelopati adalah terhambatnya perkecambahan, pertumbuhan dan produksi tanaman yang pada akhirnya tidak hanya dapat
\end{abstract}


menurunkan produksi tanaman bahkan lebih lanjut dapat mematikan tanaman.

Menurut Olofsdottera dan Mallikb (2001), penelitian alelopati akan bermanfaat dalam meningkatkan produksi tanaman pertanian dengan mengetahui jenis gulma yang mengandung alelopati dan mengetahui mekanisme kerjanya dalam mempengaruhi tumbuhan lain.

Beberapa spesies gulma yang telah diketahui mempunyai potensi alelopati diantaranya alang-alang (Imperata cylindrica), teki (Cyperus rotundus) dan Mikania micrantha. Pada akar dan batang alang-alang mengandung senyawa-senyawa penghambat pertumbuhan yaitu manitol, sakarosa, asam malat dan asam sitrat (Kusuma et al, 1992). Sedangkan pada umbi teki terkandung senyawa rkumarat, r-hidroksi, benzoate, anilat, ferolat, dan asam sitrat (Moenandir, 1993).

Penelitian Fitriana et al. (2005), menunjukan bahwa ekstrak umbi alangalang pada takaran $200 \mathrm{~g}$ per $250 \mathrm{ml}$ air dapat menekan pertumbuhan gulma sebesar 14,19 persen, dimana berat kering gulma berkurang menjadi 71,13 gram dibandingkan dengan tanpa pemberian ekstrak yaitu 81,95 gram. Dilaporkan juga bahwa esktrak Mikania micrantha ternyata dapat menurunkan daya kecambah benih padi gogo sebesar 5 persen pada konsentrasi esktrak 10 persen (Lamid et al, 2005). Lebih lanjut Lasmini (2005) melaporkan bahwa alelopati gulma dapat menurunkan hasil tanaman bawang merah sebesar $43,5 \%$.

Dari uraian diatas perlu diketahui pengaruh alelopati empat jenis gulma yang berbeda terhadap perkecambahan, pertumbuhan dan produksi tanaman bawang merah.

\section{BAHAN DAN METODE}

Penelitian dilaksanakan di kebun percobaan Fakultas Pertanian UNIHAZ di Bengkulu Utara dan Laboratorium Agronomi UNIHAZ dalam jangka waktu penelitian 4 bulan. Bahan yang digunakan dalam penelitian ini adalah benih bawang merah, pupuk kandang, pupuk $\mathrm{N}, \mathrm{P}_{2} \mathrm{O}_{5}$, dan $\mathrm{K}_{2} \mathrm{O}$, umbi alangalang (Imperata cylindrica), teki (Cyperus rutundus), Mikania micrantha, wedusan (Ageratum conyzides), pestisida, fungisida, dan pasir. Alat-alat yang digunakan adalah cangkul, parang, polybag, handsprayer, rafia, ember, timbangan, gelas ukur, dan alat tulis. Penelitian menggunakan Rancangan Acak kelompok (RAK) dengan 2 (dua) factor dalam 3 (tiga) ulangan. Faktor pertama adalah jenis ekstrak gulma (E), yaitu Ekstrak Imperata cylindrica, Cyperus rotundus, Mikania micrantha, dan Ageratum conyzoides. Faktor kedua adalah konsentrasi ekstrak gulma (K), yaitu $0 \%, 10 \%, 20 \%$, 30\%, dan $40 \%$. Setiap satuan percobaan terdiri dari tiga tanaman. Peubah yang diamati dianalisis dengan uji $\mathrm{F}$ taraf $5 \%$ dan $1 \%$ dan karena hasilnya tidak berpengaruh nyata maka data ditampilkan dalam bentuk tabulasi (grafik). Untuk evaluasi vegetasi gulma dilakukan penghitungan SDR.

Ekstrak gulma diambil dari beberapa bagian gulma, untuk gulma alang-alang dan teki ekstrak dibuat dari umbi atau rimpang, untuk gulma Mikania micrantha dan Ageratum conyzoides ekstrak dibuat dari daun dan batang gulma.

Bagian - bagian gulma tersebut diambil dari lapangan dan dibersihkan, kemudian dihaluskan dan diambil 1000 mg lalu dicampur aquadest sebanyak $1000 \mathrm{ml}$ untuk standar 100\%. Selanjutnya senyawa tersebut disimpan tempat yang gelap sambil diaduk-aduk setiap hari satu kali. Setelah tiga hari penyimpanan dilakukan penyaringan dengan kain kasa kemudian dilakukan 
pengenceran hingga didapatkan ekstrak yang sesuai dengan konsentrasi yang diinginkan.

Jumlah polibag yang digunakan adalah 180 buah dengan ukuran $30 \mathrm{~cm} x$ $45 \mathrm{~cm}$ tebal $0,2 \mathrm{~mm}$ berwarna hitam. Polibag diisi dengan media tanam berupa campuran tanah, pupuk kandang, pasir dengan perbandingan $2: 1$ : 1 hingga dua pertiga bagian polibag. Selanjutnya polibag disusun pada lahan yang telah disiapkan dengan jarak antar barisan 100 $\mathrm{cm}$ dan dalam barisan $50 \mathrm{~cm}$.

Penanaman dilakukan dengan cara membuat lubang kecil pada tanah di dalam polibag dengan menggunakan tugal, kemudian umbi diletakkan di lubang dengan bagian ujung umbi yang telah dipotong berada diatas tepat dan rata dengan permukaan tanah, kemudian ditutup dengan lapis tanah tipis.

Ekstrak gulma disemprotkan pada tanaman bawang merah secara merata pada seluruh bagian tanaman sesuai perlakuan. Aplikasi dilakukan saat bawang merah berumur 25 hari setelah tanam (HST) dan 35 HST.

Panen dilakukan bila tanaman telah menunjukkan cirri-ciri fisik yaitu daunnya sudah mulai menguning dan layu sekitar 60 - $70 \%$ dari seluruh tanaman, pangkal batang mengeras, sebagian umbi telah tersembul di atas tanah dan lapisan-lapisan umbi telah penuh berisi dan berwarna merah (Rahayu dan Berlian, 2000). Parameter yang diamati meliputi, pertumbuhan dan hasil bawang merah serta dinamika gulma.

\section{HASIL DAN PEMBAHASAN}

\section{A. Pertumbuhan dan Hasil Bawang Merah}

Dari hasil analisis sidik keragaman diketahui bahwa baik faktor ekstrak (E), faktor konsentrasi (K) maupun interaksi kedua faktor, berpengaruh tidak nyata terhadap semua peubah yang diamati. Keempat jenis gulma yang diduga mengandung alelopati ternyata tidak dapat mempengaruhi pertumbuhan bawang merah secara nyata.

Hal ini diduga karena konsentrasi ekstrak alelopati masih rendah. Faktor konsentrasi pada setiap peubah yang diamati menunjukkan hasil yang tidak konsisten dengan semakin tingginya konsentrasi ekstrak yang disemprotkan. Pada peubah tinggi tanaman dan diameter umbi, semakin tinggi konsentrasi ekstrak yang disemprotkan cenderung semakin rendah nilai hasil pengamatan (Tabel 1 dan Tabel 3). Sedangkan pada peubah jumlah daun pada umur delapan minggu setelah tanam, semakin tinggi konsentrasi ekstrak yang disemprotkan, jumlah daun cenderung meningkat hingga konsentrasi 20\%, kemudian menurun pada konsentrasi 30\% dan 40\% (Tabel 2). Demikian pula pada peubah jumlah anakan (Tabel 4), berat segar (Tabel 5) dan berat kering umbi bawang merah (Tabel 6), nilai hasil pengamatan cenderung meningkat hingga konsentrasi $20 \%$, lalu menurun pada konsentrasi 30\% dan kemudian meningkat pada konsentrasi 40\%. Masih rendahnya konsentrasi ekstrak yang disemprotkan, dengan pemeliharaan bawang merah yang baik (input pupuk yang berimbang) membuat bawang merah lebih sehat dan dapat mengurangi dampak negatif alelopati gulma. Tanaman yang sehat mempunyai dinding sel yang kuat yang membuatnya lebih tahan terhadap pengaruh luar (Mac Kown, C.T., \& D.A. Van Sanford, 1988).

Selain itu kemungkinan tidak mampu-nya ekstrak gulma yang disemprotkan menekan pertumbuhan bawang merah, diduga karena senyawa alelopati bersifat selektif. Xuan, et al., (2005) mengatakan bahwa penekanan pertumbuhan oleh alelopati bersifat selektif. Suatu spesies yang diketahui mengandung alelopati yang sangat kuat 
tidak dapat menghambat pertumbuhan setiap spesies lain. Sebagai contoh, efek alelopati alang-alang paling kuat mempengaruhi tanaman dari jenis poacea seperti padi dan jagung, sedangkan bawang merah termasuk famili Liliaceae (Rahayu dan Berlian, 2000).

Namun demikian, data hasil pengamatan menunjukkan adanya kecenderungan respon yang berbeda terhadap keempat jenis ekstrak gulma yang disemprotkan. Dalam penelitian ini ekstrak Mikania micrantha cenderung menekan pertumbuhan bawang merah. Hampir pada seluruh peubah, nilai terkecil ditemukan pada tanaman yang disemprot Mikania micrantha.

Tabel 1. Tinggi tanaman pada 8 mingu setelah tanam

\begin{tabular}{ccccccc}
\hline Perlakuan & K1 & K2 & K3 & K4 & K5 & Rerata \\
\hline E1 & 35,28 & 34,36 & 34,98 & 32,59 & 34,28 & 34,30 \\
E2 & 34,72 & 33,09 & 34,59 & 33,76 & 36,66 & 34,56 \\
E3 & 34,67 & 34,87 & 32,17 & 34,76 & 33,63 & 34,02 \\
E4 & 35,00 & 35,44 & 35,39 & 33,64 & 32,82 & 34,46 \\
\hline Rerata & 34,92 & 34,44 & 34,28 & 33,69 & 34,35 & \\
\hline
\end{tabular}

Tabel 2. Jumlah daun bawang merah pada umur $8 \mathrm{mst}$

\begin{tabular}{ccccccc}
\hline Perlakuan & K1 & K2 & K3 & K4 & K5 & Rerata \\
\hline E1 & 15,55 & 15,78 & 17,11 & 18,11 & 14,11 & 16,13 \\
E2 & 19,33 & 18,56 & 20,33 & 15,34 & 20,27 & 18,87 \\
E3 & 15,33 & 15,00 & 16,45 & 16,78 & 15,89 & 15,89 \\
E4 & 15,44 & 18,11 & 15,00 & 18,56 & 16,11 & 16,64 \\
\hline Rerata & 16,41 & 16,86 & 17,22 & 17,19 & 16,72 & \\
\hline
\end{tabular}

Tabel 3. Jumlah anakan bawang merah

\begin{tabular}{ccccccc}
\hline Perlakuan & K1 & K2 & K3 & K4 & K5 & Rerata \\
\hline E1 & 7,11 & 7,33 & 5,66 & 7,11 & 7,44 & 6,93 \\
E2 & 6,22 & 6,22 & 7,00 & 5,89 & 7,89 & 6,64 \\
E3 & 6,22 & 6,55 & 6,33 & 5,00 & 6,66 & 6,15 \\
E4 & 6,45 & 6,67 & 5,67 & 6,78 & 6,67 & 6,45 \\
\hline Rerata & 6,50 & 6,69 & 6,17 & 6,20 & 7,17 & \\
\hline
\end{tabular}

Tabel 4. Diameter umbi bawang merah

\begin{tabular}{ccccccc}
\hline Perlakuan & K1 & K2 & K3 & K4 & K5 & Rerata \\
\hline E1 & 2,027 & 1,913 & 1,953 & 1,803 & 1,620 & 1,863 \\
E2 & 2,327 & 2,113 & 1,923 & 1,803 & 2,227 & 2,079 \\
E3 & 1,933 & 2,067 & 1,723 & 1,770 & 1,460 & 1,791 \\
E4 & 1,893 & 1,947 & 1,980 & 1,887 & 1,593 & 1,860 \\
\hline Rerata & 2,045 & 2,010 & 1,895 & 1,816 & 1,725 & \\
\hline
\end{tabular}

Tabel 5. Berat segar umbi bawang merah

\begin{tabular}{ccccccc}
\hline Perlakuan & K1 & K2 & K3 & K4 & K5 & Rerata \\
\hline E1 & 1,427 & 1,347 & 1,640 & 1,450 & 1,297 & 1,432 \\
E2 & 1,467 & 1,527 & 1,600 & 1,433 & 1,597 & 1,525 \\
E3 & 1,330 & 1,557 & 1,427 & 1,203 & 1,617 & 1,427 \\
E4 & 1,250 & 1,403 & 1,313 & 1,440 & 1,173 & 1,316 \\
\hline Rerata & 1,369 & 1,459 & 1,495 & 1,382 & 1,421 & \\
\hline
\end{tabular}


Tabel 7. Berat kering umbi bawang merah

\begin{tabular}{ccccccc}
\hline Perlakuan & K1 & K2 & K3 & K4 & K5 & Rerata \\
\hline E1 & 1,297 & 1,187 & 1,440 & 1,350 & 0,993 & 1,253 \\
E2 & 1,283 & 1,360 & 1,357 & 1,000 & 1,383 & 1,277 \\
E3 & 1,110 & 1,393 & 1,243 & 1,210 & 1,497 & 1,291 \\
E4 & 1,140 & 1,207 & 1,150 & 1,220 & 1,053 & 1,154 \\
\hline Rerata & 1,207 & 1,287 & 1,297 & 1,195 & 1,232 & \\
\hline
\end{tabular}

Tabel 8. Berat kering gulma

\begin{tabular}{|c|c|c|c|c|c|}
\hline \multirow{2}{*}{ Konsentrasi } & \multicolumn{4}{|c|}{ Ekstrak } & \multirow{2}{*}{ Rerata K } \\
\hline & I.c. & C.r. & M.m. & A.c. & \\
\hline $0 \%$ & 1,13 & 1,27 & 1,36 & 0,99 & 1,19 \\
\hline $10 \%$ & 1,45 & 0,85 & 1,02 & 0,77 & 1,02 \\
\hline $20 \%$ & 0,89 & 0,93 & 0,97 & 0,94 & 0,93 \\
\hline $30 \%$ & 0,95 & 1,07 & 1,26 & 0,91 & 1,05 \\
\hline $40 \%$ & 1,12 & 0,77 & 1,44 & 1,59 & 1,23 \\
\hline Rerata E & 1,11 & 0,98 & 1,21 & 1,04 & \\
\hline
\end{tabular}

\section{B. Dominansi Gulma}

Penyemprotan berbagai jenis ekstrak gulma juga tidak memberi pangaruh nyata terhadap berat kering gulma. Hal ini diduga karena waktu aplikasi ekstrak gulma tidak tepat waktu. Menurut Premashira \& S. Zungsontiporn (2007), spesies akan lebih peka bila ekstrak disemprotkan pada umur 1-7 hst. Pada penelitian ini penyemprotan dilakukan pada umur 25 hari setelah tanam dan 35 hari setelah tanam.

Secara statistik penyemprotan ekstrak gulma tidak memberi pengaruh yang nyata terhadap berat kering gulma. Namun dari data hasil pengamatan dapat dilihat bahwa ada kecenderungan bahwa gulma pada pot yang disemprotkan Cyperus rotundus memiliki berat kering gulma yang terendah (Tabel 8).

Pertumbuhan bawang merah secara langsung berkaitan dengan keberadaan gulma di sekitar tanaman. Secara keseluruhan data peubah pada petumbuhan tanaman bawang merah yang telah dibahas di atas menunjukkan hasil yang tinggi pada penyemprtotan Cyperus rotundus. Kecenderungan rendahnya berat kering gulma membuat adanya kecenderungan tingginya pertumbuhan bawang merah. Hal ini karena kurangnya persaingan dalam mendapatkan unsur hara, cahaya, air, ruang tumbuh serta gas $\left(\mathrm{CO}_{2}\right.$ dan $\left.\mathrm{O}_{2}\right)$ untuk pertumbuhannya. Moenandir (1990) mengatakan bahwa adanya gulma di sekitar tanaman berpengaruh secara kuantitatif dan kualitatif.

Dominansi dari gulma Paspalum conjugatum diduga sangat erat kaitannya dengan sifat biologi dari gulma tersebut. Gulma paspalum memperbanyak diri dengan biji (generatif) dan stolon (vegetatif) (Soerjani et al., 1987). Diduga pada lahan yang tanahnya diambil sebagai media tanam terdapat stolon maupun biji-biji paspalum yang masih dorman. Soerjani et al., (1987) mengatakan bahwa apabila keadaan lingkungan kurang menguntungkan maka biji dan risom dalam keadaan dorman. Dalam keadaan menguntungkan, dimana tanah sudah menjadi media tanam bawang merah, maka paspalumdengan cepat mendominasi pot-pot percobaan. Sementara penyemprotan ekstrak keempat jenis gulma (E) maupun perbedaan konsentrasi ekstrak (K), 
secara statistik, belum mampu memberi pengaruh yang nyata dalam mengendalikan gulma dalam percobaan ini.

\section{KESIMPULAN DAN SARAN}

\section{A. Kesimpulan}

Dari hasil dan pembahasan di atas diperoleh kesimpulan bahwa baik faktor jenis ekstrak gulma (E) maupun konsentrasi $(\mathrm{K})$ dan interaksinya tidak berpengaruh nyata terhadap semua peubah pertumbuhan dan hasil bawang merah maupun berat kering gulma. Namun ada kecenderungan ekstark Cyperus rotundus lebih kuat menekan gulma yang tumbuh di sekitar pertanaman. Konsentrasi ekstrak menunjukkan respon yang tidak konsisten pada semua peubah yang diamati yang diduga karena masih rendahnya konsentrasi sehingga pengaruh pemeliharaan (pemupukan) lebih kuat.

\section{B. Saran}

Sangat sulit memisahkan pangaruh kompetisi dan pengaruh alelopati sehingga perlu dilakukan penelitian dalam kondisi yang lebih memungkinkan memperoleh pengaruh alelopati yang lebih jelas.

\section{UCAPAN TERIMA KASIH}

Terima kasih kepada Direktorat Jenderal Pendidikan Tinggi Departemen Pendidikan Nasional yang telah membiayai penelitian ini dengan proyek pengkajian dan penelitian Ilmu pengetahuan terapan dengan surat perjanjian pelaksanaan penelitian dosen muda nomor: 069/119.2.1/pl/2007.

\section{DAFTAR PUSTAKA}

Fitriana, M., Susilawati dan Wardani, S. 2005. Pemanfaatan Ekstrak Umbi Teki Sebagai Bioherbisida Terhadap Pertumbuhan Gulma dan
Hasil Tanaman Mentimun. Hal IV-8 - IV-12. Dalam Prosiding Implementasi Ilmu Gulma dalam Sistem Pertanian Berkelanjutan yang Berbasis Agribisnis dalam Rangka Meningkatkan Kesejahteraan Masyarakat. Konf. Nas. XVII HIGI. Yogyakarta. 20-21 Juli 2005

Kusuma, W., Winian, S., Yuputra, T., Dalimartha, S. dan Wibowo, B. 1992. Tanaman Berkhasiat Obat di Indonesia. Pustaka Kartini. Jakarta.

Lamid, S., Soelin, S. dan Mubarak, F. 2005. Potensi Pengaruh Alelopati Sembung Rambat Terhadap Pertumbuhan Benih Padi Gogo. Dalam Prosiding Implementasi Ilmu Gulma dalam Sistem Pertanian Berkelanjutan yang Berbasis Agribisnis dalam Rangka Meningkatkan Kesejahteraan Masyarakat. Konf. Nas. XVII HIGI. Yogyakarta. 20-21 Juli 2005.

Mac Kown, C.T., and D.A.Van Sanford. 1988. Nitrogen Allocation with Altered Sink Demand in Wheat. Crop Sci. 28:133-136.

Lasimini, S.A. 2005. Potensi Allelopati Dua Jenis Gulma Dominan Terhadap Pertumbuhan dan Hasil Bawang Merah. Dalam Prosiding Implementasi Ilmu Gulma dalam Sistem Pertanian Berkelanjutan yang Berbasis Agribisnis dalam Rangka Meningkatkan Kesejahteraan Masyarakat. Konf. Nas. XVII HIGI. Yogyakarta. 20-21 Juli 2005.

Moenandir, J. 1993. Ilmu Gulma Dalam Sistem Pertanian. Raja Grafindo Persada. Jakarta.

Moenandir, J. 1990. Fisiologi Herbisida. Rajawali Press. Jakarta

Olofsdottera, $\mathrm{M}$ dan Mallikb, A.U. 2001. Allelopathy Symposium; Introduction. 
(http://www.Agronomy

Journal.com diakses 10 februari 2006). 93:1-2.

Premasthira, C. And S.Zungsontiporn. 2007. Allelopathic Effect of Gooseweed (Sphenoclea zeylanica Gaertn) Extracts on Growth of Weed Seedlings. IRRI.

Radosevich, S.R. dan Holt, J.S. 1984. Weed Ecology; Implications for Vegetation Management. John Wiley and Sons. Inc. United States of America. 118-121p

Rahayu, E. dan N. Berlian. 2000. Bawang Merah. Penebar Swadaya. Jakarta.

Saidi, D. 2005. Peran Mikroorganisme pada Transformasi Residu Herbisida di Dalam Tanah. Dalam Prosiding Implementasi Ilmu Gulma dalam Sistem Pertanian
Berkelanjutan yang Berbasis Agribisnis dalam Rangka Meningkatkan Kesejahteraan Masyarakat. Konf. Nas. XVII HIGI. Yogyakarta. 20-21 Juli 2005

Soerjani, M., A.J.G.H. Kostermans, G. Tjitrosoepomo. 1987. Weeds of Rice in Indonesia. Balai Pustaka. Jakarta.

Sukman, Y. dan Yakup. 2002. Gulma dan Tehnik Pengendaliannya. Raja Grafindo Persada. Jakarta.

Xuan,T.D., T.Shinkichi, T.R. Khanh, and C.I.Min. 2005. Biologgical Control of Weed and Plant Pathogens in Paddy rice by exploiting Plant Allelopathy: An Overview. Crop Protection 24:197-206. 
Tabel 9. SDR gulma pada setelah aplikasi ekstrak gulma

\begin{tabular}{|c|c|c|c|c|c|c|c|c|c|c|c|c|c|c|c|}
\hline & 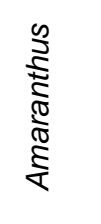 & 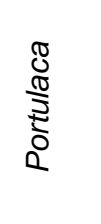 & 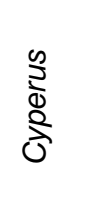 & 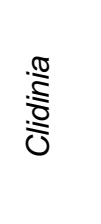 & $\begin{array}{l}\bar{\delta} \\
\text { ơ }\end{array}$ & 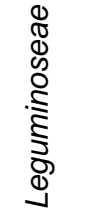 & $\begin{array}{l}\frac{\Sigma}{3} \\
\frac{\pi}{\pi} \\
\frac{2}{0} \\
\widetilde{0}\end{array}$ & 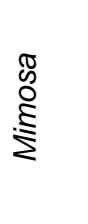 & 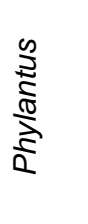 & $\begin{array}{l}\frac{\pi}{\pi} \\
\frac{0}{2} \\
\frac{1}{2} \\
\frac{2}{2}\end{array}$ & \begin{tabular}{l}
$\frac{\pi}{3}$ \\
\multirow{3}{3}{} \\
3 \\
3
\end{tabular} & $\begin{array}{l}\frac{\pi}{0} \\
\stackrel{0}{0} \\
\frac{0}{0}\end{array}$ & 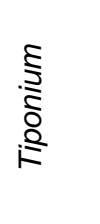 & 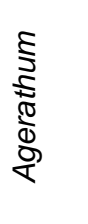 & $\begin{array}{l}\frac{n}{\mathbb{N}} \\
\frac{\mathbb{d}}{n}\end{array}$ \\
\hline E1 K1 & 11,44 & 19,61 & 19,42 & 8,85 & 0,00 & 0,49 & 34,54 & 0,00 & 0,00 & 5,62 & 0,00 & 0,00 & 0,00 & 0,00 & 0,00 \\
\hline E1 K2 & 7,24 & 34,22 & 17,19 & 5,87 & 0,00 & 0,00 & 29,62 & 0,00 & 4,67 & 0,00 & 1,18 & 0,00 & 0,00 & 0,00 & 0,00 \\
\hline E1 K3 & 4,76 & 28,35 & 10,63 & 9,00 & 7,56 & 5,79 & 20,35 & 3,77 & 0,00 & 0,00 & 0,00 & 0,00 & 0,00 & 9,82 & 0,00 \\
\hline E1 K4 & 13,39 & 11,28 & 19,91 & 0,00 & 7,04 & 8,23 & 35,81 & 0,00 & 0,00 & 3,82 & 0,00 & 0,00 & 0,00 & 0,00 & 0,00 \\
\hline E1 K5 & 5,82 & 13,19 & 14,42 & 9,40 & 12,07 & 6,19 & 31,27 & 0,00 & 2,40 & 0,00 & 2,30 & 2,96 & 0,00 & 0,00 & 0,00 \\
\hline E2 K1 & 10,75 & 13,88 & 16,88 & 16,01 & 6,19 & 0,00 & 36,27 & 0,00 & 0,00 & 0,00 & 0,00 & 0,00 & 0,00 & 0,00 & 0,00 \\
\hline E2 K2 & 13,61 & 12,54 & 10,64 & 4,04 & 4,50 & 14,58 & 28,62 & 0,00 & 4,19 & 0,00 & 3,59 & 0,00 & 0,00 & 3,68 & 0,00 \\
\hline E2 K3 & 12,07 & 26,11 & 14,37 & 0,00 & 5,51 & 3,44 & 34,89 & 0,00 & 0,00 & 0,00 & 0,00 & 0,00 & 0,00 & 3,58 & 0,00 \\
\hline E2 K4 & 10,54 & 13,94 & 13,19 & 11,54 & 0,00 & 6,48 & 27,39 & 0,00 & 7,94 & 0,00 & 5,95 & 0,00 & 3,04 & 0,00 & 0,00 \\
\hline E2 K5 & 10,22 & 13,64 & 10,15 & 10,79 & 11,15 & 3,60 & 27,27 & 0,00 & 0,00 & 5,26 & 0,00 & 5,33 & 0,00 & 0,00 & 2,62 \\
\hline E3 K1 & 9,89 & 12,83 & 14,21 & 13,42 & 4,15 & 8,78 & 27,65 & 0,00 & 2,42 & 6,68 & 0,00 & 0,00 & 0,00 & 0,00 & 0,00 \\
\hline E3 K2 & 4,51 & 23,70 & 14,62 & 7,48 & 5,42 & 4,86 & 39,38 & 0,00 & 0,00 & 0,00 & 0,00 & 0,00 & 0,00 & 0,00 & 0,00 \\
\hline E3 K3 & 5,32 & 9,40 & 12,20 & 4,10 & 0,00 & 3,58 & 40,86 & 0,00 & 0,00 & 6,18 & 8,52 & 3,34 & 0,00 & 6,51 & 0,00 \\
\hline E3 K4 & 7,69 & 21,93 & 11,76 & 8,33 & 3,97 & 9,76 & 36,57 & 0,00 & 0,00 & 0,00 & 0,00 & 0,00 & 0,00 & 0,00 & 0,00 \\
\hline E3 K5 & 10,14 & 12,77 & 18,65 & 14,98 & 7,10 & 11,16 & 17,12 & 0,00 & 2,49 & 0,00 & 2,64 & 0,00 & 0,00 & 0,00 & 2,94 \\
\hline E4 K1 & 5,46 & 8,77 & 11,00 & 19,16 & 3,40 & 0,00 & 35,15 & 0,00 & 0,00 & 3,38 & 0,00 & 0,00 & 0,00 & 7,64 & 6,04 \\
\hline E4 K2 & 11,57 & 20,85 & 16,11 & 12,57 & 0,00 & 9,40 & 24,49 & 0,00 & 0,00 & 0,00 & 0,00 & 5,01 & 0,00 & 0,00 & 0,00 \\
\hline E4 K3 & 7,47 & 23,21 & 17,69 & 14,55 & 0,00 & 0,00 & 31,80 & 0,00 & 0,00 & 0,00 & 0,00 & 5,27 & 0,00 & 0,00 & 0,00 \\
\hline E4 K4 & 18,63 & 10,50 & 11,79 & 9,39 & 4,78 & 6,19 & 28,64 & 0,00 & 7,29 & 0,00 & 0,00 & 0,00 & 0,00 & 2,79 & 0,00 \\
\hline E4 K5 & 6,34 & 19,52 & 11,16 & 8,83 & 4,76 & 6,88 & 29,63 & 0,00 & 6,70 & 2,12 & 4,08 & 0,00 & 0,00 & 0,00 & 0,00 \\
\hline
\end{tabular}

Page 8 of 54 